\title{
The Relationship between Public Debt, Budget Deficit, and Sustainable Economic Development in Developing Countries: The Role of Corruption Control
}

Vo Thi Thuy Van ${ }^{1}$, Nguyen Tran Thai Ha*1, Phan Gia Quyen ${ }^{2}$, Le Thi Hong $\mathrm{Anh}^{3}$, and Do Thanh $\mathrm{Loi}^{4}$

\section{OPEEN}

AFFILIATION:

${ }^{1}$ Saigon University, Ho Chi Minh City, Vietnam.

${ }^{2}$ University of Economics and Law, Vietnam National University, Ho Chi Minh City. Vietnam.

${ }^{3}$ Military Commercial Joint Stock Bank, Thong Nhat Branch,

Vietnam.

${ }^{4}$ Van An Phat Real Estate Joint Stock Company, Vietnam.

\section{*CORRESPONDENCE:}

nguyen.tranthaiha@sgu.edu.vn

THIS ARTICLE IS AVALILABLE IN:

http://journal.umy.ac.id/index.php/esp

DOI: 10.18196/jesp.21.1.5033

\section{CITATION:}

Van, V. T. T., Ha, N. T. T., Quyen, P. G., Anh, L. T. H., \& Loi, D. T. (2020). The Relationship Between Public Debt, Budget Deficit, and Sustainable Economic Development in Developing Countries: The Role of Corruption Control. Jurnal Ekonomi \& Studi Pembangunan, 21(1), 84-104.

\section{ARTICLE HISTORY}

Received:

5 February 2020

Reviewed:

4 March 2020

Revised:

31 March 2020

Accepted:

19 April 2020
Abstract: This study investigates the effects of public debt and budget deficits on the sustainable economic development of developing countries, taking into account the role of control of corruption. The two-step GMM method was applied for unbalanced panel data of 59 developing countries from 2004 to 2015. The study found that public debt and the budget deficit had negative effects on sustainable development, while the effect of control of corruption was positive. Moreover, using interaction terms between control of corruption and public debt and budget deficit, respectively, empirical results showed that controlling corruption limited these adverse effects. Thus, if the objective is to achieve sustainable economic development, developing countries should not see raising public debt or maintaining budget deficits as a strategy for economic development. The study contributes empirical evidence to the theory of debt overhang, crowded effects, and institutional theory in the context of developing countries. The implications are also discussed in this paper.

Keywords: Public debt; Budget deficit; Sustainable economic development; Corruption; Developing countries.

JEL Classification: H0; H62; H63; H83.

\section{Introduction}

The phenomenon of sustainable development of the economy receives much attention because it focuses on meeting the needs of the present time without impacting on future needs, according to the Report of the World Commission on Environment and Development in 1987. It can be understood that sustained development of the economy is defined as economic growth with sustainability in the long-term, and it does not focus on high growth rates but only on growth in a manner that sustains natural resources and the environment for future generations. It has been one of the prerequisite goals of government and thus received interests from researchers in looking into factors that affect sustainable development in various economies. 
The Relationship Between Public Debt, Budget Deficit, and Sustainable Economic Development ...

The role of public debt is one crucial aspect that is very prominent in the process of economic development. Its impact on economic development continuously causes debate between scholars and policy-makers due to its inconclusive results. Indeed, public debt can promote or limit the economic growth (Eberhardt \& Presbitero, 2015; Égert, 2015; Bal \& Rath, 2014; Panizza \& Presbitero, 2014; Abbas \& Christensen, 2009). Harcourt and Coddington (1984) claim that public debt in Keynesian theory stimulates economic growth because it supplies more resources for government spending to promote infrastructure, construction, education, and health care to enhance the productive capacity of an economy. It also increases consumption as well as aggregate demand for goods, services, and employment of the economy at that time. However, prior studies show that the adverse effects of public debt on economic growth are noticeable (Hussain, Haque, \& Igwike, 2015; Anita, Ana, \& Martina, 2014; Zouhaier \& Fatma, 2014; Calderón \& Fuentes, 2013; Šimić \& Vinko, 2012). An exceed rate of public debt is a primary result of low savings rates of a nation, and it leads to a reversal effect, which is called the debtoverhang effect (Reinhart, Reinhart, \& Rogoff, 2012). This effect occurs when the proportion of public debt is higher than a country's ability to repay its debt. Consequently, the nation's costs associated with debt's borrowing become relatively expensive, so it puts pressure on domestic and foreign investment shortly.

Moreover, crowding-out effects are seen as a cause of the negative effect of public debt on economic growth (Gochoco, 1990; Liaqat, 2019). According to Elmendorf and Mankiw (1999), a high ratio of public debt is the result of a prolonged situation of a budget deficit. The government continuously borrows to spend or invest, and it has the intention to increase interest rates that lead to a reduction in private investment spending, thus creating the crowding-out effect (Buiter, 1977; Morrissey \& Udomkerdmongkol, 2012). Therefore, public debt is considered as an indirect reason to reduce the economic growth of countries due to the exceed spending of government. Recently, Pattillo, Poirson, \& Ricci (2011) developed a theory on the relationship between public debt and economic growth through the proposal of a model of endogenous growth. The authors argued that public debt could have positive or negative effects on economic growth depending on the public debt proportion, and it is supported by the studies by Wright and Grenade (2014) and Afonso and Alves (2014) in recent years.

Meanwhile, caution in implementing fiscal policy is one of the essential pillars for economic development. However, the state budget deficit has become a common phenomenon in most countries, including developing countries and developed countries (Tung, 2018). Rodrik (2005) emphasizes that both financial solvency and well-established property rights are considered as a prerequisite for achieving significant and stable economic growth. However, the budget deficit and its role in economic development are still controversial. On the one hand, Okelo, Momanyi, Othuon, and Fredrick (2013) showed that budget deficits could help economic growth because it helped to increase the efficiency of restructuring, education, and social welfare, thereby promoting economic growth. Moreover, a low budget deficit could help to reduce the occurrence of economic crisis and future risks of high and inconsistent public debt levels (Clements, Gupta, \& Inchauste, 2004; Baldacci, Cui, Clements, \& Gupta, 2004). One the other hand, 
The Relationship Between Public Debt, Budget Deficit, and Sustainable Economic Development ...

the budget deficit could cause an increase in the cost of financial debt, thereby leading to financial burdens and loss of competitiveness of the economy (Gaber, 2010).

Moreover, Cohen, Hawawini, Maier, Schwartz, \& Whitcomb (1983) indicated that institutional quality plays a vital role in the growth, and it is measured by bureaucracy, corruption, property rights, and laws and regulations. Some studies suggest that corruption can be considered as the main factor in explaining the difference in the influences of public debt and budget deficit, which is found by previous studies (Madni \& Chaudhary, 2017; Barişik \& Baris, 2017; Kim, Ha, \& Kim, 2017). The authors argued that corruption could cause an increase in public debt, but the negative effect of public debt on economic growth became stronger in the countries where the corruption level was high with low transparency (Cooray, Dzhumashev, \& Schneider, 2017). The authors found that the improvement in institutional conditions promotes higher effectiveness of the fiscal policy. The author suggested that the good institutional aspects, such as government effectiveness, regulatory quality, and control of corruption, enhance the positive impacts of government expenditure on economic growth. Similarly, other studies showed that corruption reduced economic investment (Mauro, 1995; Campos, Lien, \& Pradhan, 1999), foreign direct investment (Abed \& Davoodi, 2000), tax revenue (Wei, 2000), labor productivity (Lambsdorff, 2003), and increase the inflation (Al-Marhubi, 2000; Blackburn, Bose, \& Emranul Haque, 2006), as well as shadow economy (Schneider Buehn, \& Montenegro, 2010). It claims that the effects of corruption are presented in various aspects of the economy, and they need to be considered in more detail.

However, previous studies have left significant academic gaps in research on sustainable economic development in two aspects: (1) There have been many studies conducted on both theoretical and empirical analysis to find the influences of public debt or budget deficit to economic growth in short-term, but the results have been inconsistent; (2) There has been a significant shortage of studies on the relationship among public debt, budget deficit, and sustainable economic growth in long-term, especially in developing countries. Moreover, most previous studies focused on explaining the relationship among public debt, budget deficit, and economic growth while ignoring the role of corruption as a critical factor in explaining the differences in their results of these studies. The role of corruption control, budget deficit, and public debt for sustainable economic development have not been fully mentioned in previous studies. Thus, this study makes new contribution to the literature by directly addresses the aforementioned research gaps. The study also contributes to the theory and practice of determining the effects of public debt on sustainable economic development in the context of developing countries. This study is organized into five sections: Section one presents an overview of the study; Section two discusses the relevant theories and prior studies; Section three describes the variables, empirical models and methods; Section four presents and discusses the results; Finally, section five provides main summaries and implications.

Economic growth, which is measured as a percentage change of the gross domestic product (GDP) or gross national product (GNP), may be positive or negative in different periods. Negative economic growth reflects the recession, whereas positive economic growth reflects the expansion of an economy. It can be seen that economic growth occurs 
The Relationship Between Public Debt, Budget Deficit, and Sustainable Economic Development ...

when resources are exploited most effectively and reasonably (Matiti, 2013). However, Malthus and Ricardo (in Wrigley, 1998) argued that the scarcity of national resources could create limits to economic development, population growth, and personal income. Therefore, the concept of sustainable economic development, referring to the optimal management of renewable resources, has received much attention from many leaders and researchers in the world (Figuières, Masclet, \& Willinger, 2012). In 1987, the Brundtland Report entitled "Our Future" defined sustainable economic development as meeting the needs of the present time without any harmful effect on future needs (Commission World of Environment and Development, 1987). It can be noted that sustained economic development can be defined as an economic growth connecting with sustainable aspects in the long-term (Pezzey, 1992). It is not focused on a high rate of economic growth but instead maintains sustainable growth by sustaining natural resources and the environment for future generations. In empirical studies, sustainable economic development can be measured as an increase in GDP at present compared to a given year in the past, such as a percentage change in GDP at the current year compared to GDP in four years ago (Kim et al., 2017).

Sustainable economic development and public debt

Public debt is one of the critical aspects of economic development due to its ability to make financial resources for the economy. However, the Keynesian model argues that no real burden is associated with public debt and that it has no significant impact on economic growth (Metwally \& Tamaschke, 1994). The real burden happens at the time government spending is made when real resources are used up. Public debt is a debt that the government owes to its economic sectors; it within the country does not complement its real resources. Meanwhile, the public debt of external sectors is different because external public debt can supplement the nation's real resources, and they must be returned within a particular time. The replacement of the current tax by public debt brings a macroeconomic expansion immediately because an increase in government spending financed by tax increases will create a different and low multiplier than financed by public debt. Thus, public debt can boost the nation's economic growth. According to the Keynesian model, public debt is not a factor in narrowing the fiscal policy (Savvides, 1992).

However, the opposite effect of public debt on economic growth can be explained by using the theory of debt overhang effect. Krugman (1988) identifies that public debt as a situation in which investment is reduced or delayed because the private's profits from its investments will be considered to use for paying public debt. It implies that future public debt is expected to increase with the nation's output. As a result, the level of public debt will increase uncertainty behavior among investors regarding the policies that the government applies to pay its debt obligations. In this view, he argues that most potential investors would assume that the government would finance their debt obligations through increasing tax rates in the economy in the near future, and it leads to the dilemma of private investors. These investors will wait or delay to observe how their investment and economic growth will be affected by an increase in public debt. Consequently, a higher proportion of public debt will have a negative effect on macroeconomic stability in the economy in the next years. It is illustrated by a limitation of capital flows while 
The Relationship Between Public Debt, Budget Deficit, and Sustainable Economic Development ...

occurring the capital flight in the economy (Alesina, Mirrlees, \& Neumann, 1989; Cerra, Rishi, \& Saxena, 2008). It makes economic development to become unstable. Empirical evidence supporting the debt overhang effect is given, such as Reinhart et al. (2012); Hwang, Chung, and Wang (2010); Sen, Kasibhatla, and Stewart (2007); and Chowdhury (2001).

In addition, the crowded-out effect is seen as another approach to investigate the effect of public debt on economic growth (Heutel, 2012; Liaqat, 2019). According to Elmendorf and Mankiw (1999), public debt is often used by countries to offset the deficit of state budget, and it often crowds out for private investments. It is claimed that loans will often lead to a rise in the interest rates when the government wants to increase the ratio of public debt. As soon as there is an increase in interest rates, it may reduce or put the private sectors to ignore their investments in the economy. The decline in private investment means that the whole economy will have low available capital for its operation, and it will reduce future economic growth. Therefore, it can be seen that the higher public debt, the greater the crowded-out effect is created for private investment. Consequently, the economic fluctuation will be created, and the high public debt will hinder the sustainable economic development of nations due to uncertainties in the future.

\section{$\boldsymbol{H}_{1}$ : Public debt has a negative effect on sustainable economic development}

\section{Sustainable economic development and budget deficit}

The impact of budget deficits can be explored from two different sides: positive or negative, long-term or short-term. On the positive side, the budget deficit is considered as an expanded fiscal policy to alleviate economic fluctuations related to external shocks, coping with economic recession (Clements et al., 2004; Baldacci et al., 2004). Okelo et al. (2013) imply that budget deficits can help economic growth because it helps increase the efficiency of economic restructuring, providing more resources to invest in education, infrastructure, and social welfare. The Keynes model also shows that by increasing the budget deficit, the government can expand spending and increase the aggregate demand of the economy, thus increasing the economy. However, the impact of budget deficits on economic growth is only significant in the short-term (Karras, 1994). Moreover, the use of budget deficits to stimulate growth can only be effective in the context of declining aggregate demand (for example, in the case of recession or crisis). When the economy is operating at full employment (there is no excess of production factors), increasing the budget deficit will not only affect aggregate demand but also threaten to increase of inflation for the economy (Van \& Sudhipongpracha, 2015). In turn, a high inflation rate reduces aggregate demand, increases unemployment, it causes instability in the socioeconomic environment, the stability of macroeconomic growth is significantly affected (Barro, 1995; Bruno \& Easterly, 1998).

Besides, budget deficits can cause an increase in the cost of financial debt, thereby threatening the sustainability of fiscal policy as it leads to an increase in public debt 
The Relationship Between Public Debt, Budget Deficit, and Sustainable Economic Development ...

(Agnello \& Sousa, 2013). Woo (2003) argues that these fiscal policy results are in the presence of income inequality. It leads to strong effects that impede fiscal policies to show at a lower level of capital accumulation, and thus growth to collapse. Policymakers use budget deficits to meet their short-term goals, and they conflict with maintaining longterm macroeconomic stability. It happens because policymakers may disagree with government spending components that will ultimately lead to distribution failures and determine government spending levels. In addition, shocks related to the level of government revenue will lead to many changes in government spending and, in turn, cause fiscal fluctuations next year. Khan, Khan, \& Zaman (2012) found that both government spending and budget deficits had adverse impacts on economic growth in Pakistan between 1980 and 2010. Earlier, Fatima, Ahmed, \& Rehman (2012) used timeseries data from 1978-2009 to examine the effects of budget deficits on economic growth in Pakistan; they found evidence of an inverse relationship between these two indicators. Therefore, the budget deficit is said to have a negative relationship with the sustainable development of the economy in the long-term.

\section{$\boldsymbol{H}_{2}$ : Budget deficit has a negative effect on sustainable economic development}

\section{Sustainable economic development and corruption}

Institutional theory has recently been integrated to explain economic relations more clearly (Cooray et al., 2017; Ha et al., 2019; Phung, Van, Thuong, \& Ha, 2019). North (1990) implies that institutional perspectives are the rules or regulations for the functioning of society, which are the foundation for interaction among residents and organizations. Kim et al. (2017) suggest that a better institutional environment can promote higher levels of investment, and it can lead to sustained economic growth. Moreover, a good institutional environment can also reduce the instability of the economic decision of policymakers and encourage more creative and productive activities. Égert (2016) showed that regulations and institutional quality could affect the productivity of OECD countries. Dort, Méon, \& Sekkat (2014) provide empirical evidence to confirm that national investment promotes economic growth in countries with good institutional quality. Bergeen et al. (2015) found that institutional quality was positively correlated with the economic growth of 35 countries in Europe. Phung et al. (2019) investigate a decisive intermediate role for institutional quality in promoting the relationship between innovation and economic growth. At the enterprise level, $\mathrm{Ha}$ et al. (2019) revealed that the institutional environment would enhance firm profitability because it creates a comparative and transparent environment.

The role of institutional quality is essential in the functioning of the economy and society. However, the measurement of institutional quality is a controversial issue. One of the widely applied measurements of institutional quality is the level of corruption (Kim et al., 2017). A high level of corruption will have a significant opposite effect on sustainable economic development, through causing adverse effects to other macroeconomic factors. Many previous studies have explained the impact of corruption on economic growth, and most studies have found a negative correlation between these two indicators, for 
The Relationship Between Public Debt, Budget Deficit, and Sustainable Economic Development ...

example, Mauro (1995); Tanzi and Davoodi (2001). A country with low corruption will be able to increase investment, reduce inflation, increase national productivity, leading economic growth. For example, prior studies find that corruption will reduce investment (Mauro, 1995; Campos et al., 1999; Brunetti \& Weder, 2003) and foreign direct investment as well as tax revenue (Abed \& Davoodi, 2000; Wei, 2000). Lambsdorff (2003) argues that corruption would reduce labor productivity. High corruption is a testament to the disadvantage of the economy through higher inflation (Al-Marhubi, 2000; Blackburn et al., 2006). Corruption has the potential to significantly damage economic efficiency through the allocation of resources in the market system, disrupting competition, leading to innovation and brain drain in a country and beyond. It leads to an uncomfortable business environment, lower growth rate with lower tax revenue and higher public debt, so preventing economic development (Tarek \& Ahmed, 2017). Therefore, this study proposes that corruption control plays an active role in reducing the negative effects of corruption, thereby promoting sustainable economic development.

\section{$\boldsymbol{H}_{3}$ : Corruption control has a positive impact on sustainable economic development.}

Sustainable economic development, public debt, budget deficit, and corruption

Studies on budget deficits and budget deficits and their determinants have focused on macroeconomic indicators and ignored the intermediate impact of institutional quality. Alesina et al. (1989) support the idea that macroeconomic indicators are not only sufficient to explain budget deficits, concerns for the impact of institutional factors on the budget deficit. By emphasizing the importance of the institutional framework of the economy, it helps ensure the sustainability of good macroeconomic policies. However, budget overspending will have a major impact if accompanied by high levels of corruption because the revenue and expenditure aspects of government budgets are strongly affected by corruption. In terms of revenue, less revenue is due to bribes by public officials, while government spending is misleading or misrepresented for their composition (Chowdhury \& Michael Geringer, 2001). Corruption leads to budget deficits when public revenue decreases, while public spending simultaneously increases. The inefficiency of this system exacerbates the implementation of sound fiscal policy (Lambsdorff, 2003; Tanzi \& Zee, 1997). It creates a vicious cycle of corruption and borrowing in the near future and causes unstable economic growth. Therefore, controlling corruption will reduce the adverse effects of the budget deficit on sustainable economic development.

$\boldsymbol{H}_{4}:$ The interaction between budget deficit and corruption control has a positive impact on sustainable economic growth.

In addition, a high deficit leads to an increase in public debt, while the resources allocated to repaying public debt become a constraint on productivity growth and will create a crowded effect (Heutel, 2012; Liaqat, 2019). Existing literature indicates that corruption distorts public spending and leads to suboptimal government spending (Cooray et al., 
The Relationship Between Public Debt, Budget Deficit, and Sustainable Economic Development ...

2017; Tanzi \& Davoodi, 2001). Kaufman (2010) argues that a government finances its spending by increasing debt, in the case of corruption, which means that, once again, a higher debt is required, leading to a higher debt servicing cost. This practice of corruption increases public debt and future repayment costs, thereby reducing the positive results of sustainable economic development. Therefore, controlling corruption will limit the inefficiency of public debt on sustainable economic development.

$\boldsymbol{H}_{5}$ : The interaction between public debt and corruption control has a positive impact on sustainable economic growth.

\section{Research Method}

In order to estimate the effects of public debt on sustainable economic development, this study developed empirical models for panel data that was used by Woo and Kumar (2015) and Kim et al. (2017). Then, the study improved Equation (1) to Equation (2) to check the influence of corruption control to sustainable economic development, as follows:

growth $_{i t}=\beta_{0} * \log \left(y_{i t-4}\right)+\beta_{1} *$ debt $_{i t-4}+\beta_{2} *$ deficit $_{i t-4}+\beta_{3} *$ corruption $_{i t-4}+\gamma * X_{i t-4}+\varepsilon_{i t}$

Where $i$ and $t$ illustrate the countries and the time periods, respectively $(i=1, \ldots, 59$ and $\mathrm{t}=2004, \ldots, 2015)$. According to Kim et al. (2017), growth it $_{\text {it }}$ a dependent variable, and it is represented by the sustainable economic development of country $i$ at $t$ time. It is defined by the average growth rate of real GDP per capita of country i over a period of four years. Then, it is as follow:

growth $_{i t}=\frac{1}{4} * \frac{G D P P C_{i t}-G D P P C_{i t-4}}{G D P P C_{i t-4}}$

The initial GDP per capita is controlled for with $\log \left(y_{i t-4}\right)$. Moreover, $d e b t_{i t-4}$ and deficit $_{i t-4}$ are the public debt ratio and the difference between spending and revenue ratio of country $i$ at the beginning of the period. corruption $_{i t-4}$ is the level of corruption at the t-4 time ago of country i. corruption it $-4_{4}$ is corruption level of country $i$ at the beginning of the period, represented by two indicators: (1) the level of corruption control which is collected from the World Governance Indicator (WGI) of Worldbank, and (2) the corruption index comes from the International Country Risk Guide (ICRG). An increase in these two variables implies a low level of national corruption. $X_{i t-4}$ is a vector of other control variables, and $\gamma$ is a vector of coefficients for those control variables (see more at Table 1). They are often used by many studies in economic growth, such as Phung et al. (2019), Kim et al. (2017), Ha and Quyen (2018), Barro and Lee (2013), and Blackburn et al. (2006). The last term, $\varepsilon_{i t}$ is the idiosyncratic error term. 
Van, Ha, Quyen, Anh, \& Loi

The Relationship Between Public Debt, Budget Deficit, and Sustainable Economic Development ...

Table 1 Description of variables

\begin{tabular}{|c|c|c|c|}
\hline Variables & Abbreviation & Measurement & Database \\
\hline \multicolumn{4}{|l|}{ Dependent variable } \\
\hline $\begin{array}{l}\text { Sustainable economic } \\
\text { development }\end{array}$ & Growth & $\frac{1}{4} * \frac{G D P P C_{i t}-G D P P C_{i t-4}}{G D P P C_{i t-4}}$ & World bank \\
\hline \multicolumn{4}{|l|}{ Independent variables } \\
\hline Public debt & Debt & $\begin{array}{l}\text { The ratio between public debt and } \\
\text { GDP. }\end{array}$ & IMF \\
\hline Budget deficit & Deficit & $\begin{array}{l}\text { The ratio between the difference } \\
\text { from spending to revenue of } \\
\text { government with GDP. }\end{array}$ & World Bank \\
\hline Corruption 1 & Corr1 & $\begin{array}{l}\text { Corruption index from The } \\
\text { International Country Risk Guide. }\end{array}$ & ICRG \\
\hline Corruption 2 & Corr2 & $\begin{array}{l}\text { The indicator of control of } \\
\text { corruption from the World } \\
\text { Governance Indicator. }\end{array}$ & World Bank \\
\hline \multicolumn{4}{|l|}{ Control variables } \\
\hline Human capital & Human & $\begin{array}{l}\text { The human capital index is collected } \\
\text { from the database of Barro and Lee. }\end{array}$ & $\begin{array}{l}\text { Barro and } \\
\text { Lee }\end{array}$ \\
\hline Government size & Govsize & $\begin{array}{l}\text { The ratio between government } \\
\text { spending and GDP. }\end{array}$ & World Bank \\
\hline Trade openness & Trade & $\begin{array}{l}\text { The ratio is calculated by the total of } \\
\text { export and import on GDP. }\end{array}$ & World Bank \\
\hline Inflation & $\operatorname{lnfl}$ & $\begin{array}{l}\text { The ratio in the change in price } \\
\text { consumption. }\end{array}$ & World Bank \\
\hline
\end{tabular}

Source: Author, 2020

In order to estimate the interactive effects of corruption and public debt on sustainable economic development, this study improved Equation (1) to Equation (3). The model was developed with the interaction term among public debt and control of corruption, as follows:

growth $_{i t}=\beta_{0} * \log \left(y_{i t-4}\right)+\beta_{1} * \operatorname{debt}_{i t-4}+\beta_{2} *$ deficit $_{i t-4}+\beta_{3} * \operatorname{debt}_{i t-4} *$ corruption $_{i t-4}+\gamma * X_{i t-4}+\varepsilon_{i t}$

debt $_{i t-4} *$ corruption $_{i t-4}$ is an interaction variable between the public debt ratio and the level of corruption at the beginning of the period of country i. From Equation (3), it can be seen that the marginal effect of public debt on sustainable economic development would be determined as a function of the dependent variable of corruption. Particularly, the equation of dependent corruption is as follows:

$\frac{\partial\left(\text { growt }_{i t}\right)}{\partial\left(\text { debt }_{i t-4}\right)}=\beta_{1}+\beta_{3} *$ corruption $_{i t-4}$

Based on Equation (4), it can be seen that if the corruption indicator at the t- 4 time is smaller $-\beta_{1} /_{3}$ of public debt, it will hinder the sustainable economic development. However, if the corruption indicator at $\mathrm{t}-4$ time is greater $-\beta_{1} / \beta_{3}$ of public debt, it will be 
The Relationship Between Public Debt, Budget Deficit, and Sustainable Economic Development ...

able to boost sustainable economic development. We note that the corruption indicator has a negative relation with the level of national corruption.

In order to estimate the interactive effects of corruption and budget deficit on sustainable economic development, this study transformed Equation (1) to Equation (5). The model was developed with the interaction term among public debt and control of corruption, as follows:

growth $_{i t}=\beta_{0} * \log \left(y_{i t-4}\right)+\beta_{1} *$ debt $_{i t-4}+\beta_{2} *$ deficit $_{i t-4}+\beta_{3} *$ deficit $_{i t-4} *$ corruption $_{i t-4}+\gamma * X_{i t-4}+\varepsilon_{i t}$

de $_{\text {ficit }}$ it $-4 *$ corruption $_{i t-4}$ is an interaction variable between the budget deficit ratio and the level of corruption at the t-4 time of country i. From Equation (5), it can be seen that the marginal effect of budget deficit on sustainable economic development would be determined as a function of the dependent variable of corruption. Mainly, the equation of dependent corruption is as follows:

$\frac{\left.\partial \text { (growt }_{\text {it }}\right)}{\partial\left(\text { deficit }_{i t-4}\right)}=\beta_{1}+\beta_{3} *$ corruption $_{\text {it }-4}$

Based on Equation (6), it can be seen that if the corruption indicator at the t- 4 time is smaller $-\beta_{1} / \beta_{3}$ of the budget deficit, it will hinder the sustainable economic development. However, if the corruption indicator at the $\mathrm{t}-4$ time is greater $-\beta_{1} / \beta_{3}$ of the budget deficit, it will be able to boost sustainable economic development. We note that the corruption indicator has a negative relation with the level of national corruption

Methodology

Prior growth models' predictions were somewhat inconsistent with observations from reality because factors such as human capital and government spending, which have become endogenous factors behind economic development. Empirical analysis using Ordinary least squares (OLS) did not bring valid and reliable results due to bias and inconsistent regression. Therefore, this study applied the two-step system Generalized Method of Moments (two-step sys-GMM) to deal with heterogeneity, serial correlation, and endogenous issues (Kim et al., 2017). The study used the lags of the dependent variable and control variables as instrument variables for GMM estimations because of their endogenous effect in models. The Hansen test was employed for the validity and robustness of estimations, while the Arellano-Bond test AR (2) showed the autocorrelation for residual (Roodman, 2009).

\section{Result and Discussion}

Macro data for this study were collected from the databases of World bank, International Monetary Fund (IMF), as well as Barro and Lee's database, while corruption indices were 
Van, Ha, Quyen, Anh, \& Loi

The Relationship Between Public Debt, Budget Deficit, and Sustainable Economic Development ...

Table 2 Descriptive Statistics

\begin{tabular}{lccccc}
\hline \multicolumn{1}{c}{ Variables } & Mean & St. Deviation & Min & Median & Max \\
\hline Gdppcgr & 0.1104 & 0.0698 & -0.0028 & 0.0965 & 0.6868 \\
Debt & 0.5349 & 0.3688 & 0.0587 & 0.4339 & 2.3618 \\
Corr1 & 2.1233 & 0.7292 & 0.0000 & 2.0000 & 5.0000 \\
Corr2 & 0.4224 & 0.1805 & 0.0000 & 0.4084 & 1.0000 \\
infl & 10.293 & 19.733 & -7.714 & 6.933 & 418.019 \\
Gsize & 12.910 & 5.196 & 0.000 & 13.200 & 31.527 \\
Trade & 70.946 & 34.587 & 0.000 & 66.499 & 220.407 \\
Human & 2.0896 & 0.5803 & 1.0695 & 2.0738 & 3.3016 \\
Deficit & -0.658 & 4.769 & -17.302 & -0.767 & 40.340 \\
Log(yit-4) & 11.005 & 2.361 & 4.965 & 10.652 & 17.277 \\
\hline
\end{tabular}

Source: Author, 2020

obtained from The International Country Risk Guide and Worldwide Governance Indicators. We note that this study attempted to collect data as much as possible, but some primary data were limited (for example, debt ratio by IMF and corruption index by ICRG). Thus, the collected data covered 59 developing countries from 2004 to 2015 after excluding lacked data (see the list of selected countries in Appendix 1). They were organized into unbalanced panel data for GMM estimations.

It can be seen that sustainable economic development represented by GDPPCGR had an average value of 0.1104 and a standard deviation of 0.0698 . These results imply that GDP per capita of countries generally increased by $11.04 \%$ during the previous four years, and there was a significant difference in the sustainable economic development of countries. Similarly, the public debt of countries four years ago had an average value of 0.5349 , showing the proportion of public debt in national GDP four years ago. Kazakhstan in 2011 had the lowest public debt ratio with 0.05874 of LDEBT, while Nicaragua in 2007 with 2,3618 LDEBT was a country with the highest public debt ratio in the four years ago. Moreover, based on the largest and smallest values of corruption indicators, it can be seen that there was a significant deviation between countries in the research sample with 2.1233 mean and 0.7292 standard deviations (ICRG). The average value was 0.4224 , and the standard deviation was 0.0698 when considering with WGI.

First, the study estimated the impact of corruption and public debt on countries' sustainable economic growth, in which corruption was represented by the level of control of corruption from WGI. An increase in this index implies a low level of corruption. The results are presented in Table 3 and Table 4. It can be seen that both AR (2) and Hansen tests produced a p-value of $10 \%$ higher than statistical significance. It implies that autocorrelation in the research model did not occur when using GMM estimates, while the instrument variables were not correlated with residuals. Thus, our findings were robust and reliable, and they could be used to interpret and discuss implications. 
Van, Ha, Quyen, Anh, \& Loi

The Relationship Between Public Debt, Budget Deficit, and Sustainable Economic Development ...

Table 3 The relationship between public debt, budget deficit, and sustainable economic development

\begin{tabular}{|c|c|c|c|}
\hline \multirow{2}{*}{$\begin{array}{c}\text { Independent } \\
\text { variable: } \\
\text { GDPPCGR }\end{array}$} & \multirow[b]{2}{*}{ Model (1) } & \multicolumn{2}{|c|}{ Model (2) } \\
\hline & & $\begin{array}{l}\text { Corruption indicator 1: } \\
\text { ICRG (1) }\end{array}$ & $\begin{array}{l}\text { Corruption indicator 2: WGI } \\
\text { (2) }\end{array}$ \\
\hline $\log (\mathrm{Gdppc})$ & $\begin{array}{c}-0.09598 * * * \\
{[-54.20]}\end{array}$ & $\begin{array}{c}-0.09084 * * * \\
{[-50.22]}\end{array}$ & $\begin{array}{c}0.08347^{* * *} \\
{[-31.96]}\end{array}$ \\
\hline Debt & $\begin{array}{c}-0.05271 * * * \\
{[-15.26]}\end{array}$ & $\begin{array}{c}-0.04816 * * * \\
{[-15.62]}\end{array}$ & $\begin{array}{c}-0.04935 * * * \\
{[-12.81]}\end{array}$ \\
\hline Deficit & $\begin{array}{c}-0.00108 * * * \\
{[-21.50]}\end{array}$ & $\begin{array}{c}-0.00095 * * * \\
{[-26.56]}\end{array}$ & $\begin{array}{c}-0.00072 * * * \\
{[-16.01]}\end{array}$ \\
\hline Corr1 & & $\begin{array}{c}0.00310^{*} \\
{[1.77]}\end{array}$ & \\
\hline Corr2 & & & $\begin{array}{c}0.02570 * \\
{[1.83]}\end{array}$ \\
\hline Gsize & $\begin{array}{c}0.00180 * * * \\
{[14.71]}\end{array}$ & $\begin{array}{l}0.00182 * * * \\
{[10.26]}\end{array}$ & $\begin{array}{l}0.00138 * * * \\
{[10.67]}\end{array}$ \\
\hline Infl & $\begin{array}{c}0.00058 * * * \\
{[52.65]}\end{array}$ & $\begin{array}{l}0.00062^{* * *} \\
{[23.07]}\end{array}$ & $\begin{array}{c}0.00078 * * * \\
{[26.45]}\end{array}$ \\
\hline Trade & $\begin{array}{l}0.00043^{* * *} \\
{[10.17]}\end{array}$ & $\begin{array}{c}0.00065^{* * *} \\
{[19.83]}\end{array}$ & $\begin{array}{l}0.00079 * * * \\
{[15.96]}\end{array}$ \\
\hline Human & $\begin{array}{l}0.13398 * * * \\
{[9.72]}\end{array}$ & $\begin{array}{l}0.08857^{* * *} \\
{[6.79]}\end{array}$ & $\begin{array}{c}0.04605^{* * *} \\
{[3.25]}\end{array}$ \\
\hline Const. & $\begin{array}{c}0.85645^{* * *} \\
{[39.13]}\end{array}$ & $\begin{array}{l}0.87546 * * * \\
\quad[33.05]\end{array}$ & $\begin{array}{l}0.86668 * * * \\
{[32.93]}\end{array}$ \\
\hline $\operatorname{AR}(1)$ & 0.542 & 0.517 & 0.276 \\
\hline $\operatorname{AR}(2)$ & 0.853 & 0.844 & 0.993 \\
\hline Hansen & 0.259 & 0.209 & 0.236 \\
\hline Num. group & 59 & 59 & 59 \\
\hline Num. IV & 59 & 59 & 59 \\
\hline Obs & 677 & 677 & 677 \\
\hline
\end{tabular}

Note: $\left({ }^{*}\right),(* *)$, and $(* * *)$ are $10 \%, 5 \%$, and $1 \%$, respectively, $z$-statistic in [ ]

Source: Author, 2020

The results presented in Table 3 show that the coefficients of Debt in the model (1) and (2) are from -0.04817 to -0.05271 , and both coefficients are statistically significant at level $1 \%$. These findings showed that a $1 \%$ increase in public debt in the previous four years would reduce from $0.04817 \%$ to $0.05271 \%$ in sustainable economic development. In other words, public debt will impede the sustainable economic growth of nations. Our results are similar to the previous findings of DiPeitro and Anoruo (2012), Šimić and Vinko (2012), and Panizza and Presbitero (2013). It can be interpreted in terms of overhang-debt and crowding-out effects. According to the overhang debt theory, high public debt is an uncertain situation in which domestic investment is reduced or delayed because potential investors would assume that the government would finance their debt obligations through increasing tax rates in the economy, and they think that their profits will be used to pay the public debt (Krugman, 1988). Moreover, a high ratio of public debt implies that the interest rate will be raised when the government wants to borrow more debt. In turn, the high-interest rate causes a reduction in private investment, and the usable capital of the economy will fall to a low level. Besides that, according to the crowding-out effect, 
The Relationship Between Public Debt, Budget Deficit, and Sustainable Economic Development ...

public debt is often used by countries to offset the state budget deficit, and the expansion of government spending is also the main factor that eliminates out private investment (Elmendorf \& Mankiw, 1999). Consequently, sustainable economic development will be influenced by the increase of uncertainty among investors regarding the policies that the government applies to pay its debt obligations.

The budget deficit was found as an inverse correlation with sustainable economic growth with a statistical significance of $1 \%$. Deficit coefficients ranged from $-0,00072$ to 0.00108 , suggesting that countries with high deficits were more constrained by sustainable economic growth. Our results confirmed that the budget deficit could lead to an increase in public debt in the long term. It could also lead to inefficient resource allocation. In the future, the government must prioritize resources when allocated to pay public debt. Besides, the budget deficit brings limitations to the productivity of the economy and will create a crowded effect. On the one hand, the budget deficit threatens the stability of the economy in the future as the problem of external debt and debt service has continued to increase over time (Ali \& Mustafa, 2012). On the other hand, it leads to a negative impact on investment. Private investment is negatively affected by internal and external debt service, total debt stock, and tax burden. Public borrowing after a prolonged fiscal deficit leads to a financial outburst because it accounts for savings that can be used for private investment (Ali \& Mustafa, 2012; Chowdhury, 2001). As a result, long-term sustainable growth of the economy is significantly reduced when the budget deficit is prolonged.

The regression coefficients of the variables represented for control of corruption ranged from 0.00310 to 0.02570 , respectively, with a statistical significance of $10 \%$. They showed that if corruption were well controlled, represented by an increase in the value of Corr1 (ICRG) and Corr2 (WGI), sustainable economic growth would increase from 0.00310 to 0.002570 . Our results illustrate the critical role of control of corruption in economic development. Controlling corruption will minimize conflicts in the distribution of national resources, reduce the loss of government revenue, increase the competitiveness and transparency of the business environment. As a result, investment activities will be promoted; trust in the business environment will be improved. In turn, they will promote stable economic development in the long term (Mauro, 1995; Tanzi \& Davoodi, 2001; Kim et al., 2017).

The role of control of corruption is also reflected in the ability to control the negative impact of budget deficits and public debt, which are shown in Table 5. The coefficients of the interaction variable between public debt and corruption, Interact1 and Interact2, received 0.01681 and 0.08541 , respectively. Our findings suggested that countries with low levels of corruption would restrict the negative impact of public debt on sustainable economic growth. In other words, countries with low levels of corruption would have higher levels of sustainable economic development when increasing their public debt than countries with high levels of corruption. Our results are similar to the findings of Kim et al. (2017). Based on Equation (4), we also found that the threshold value of control of corruption was 4.92 and 0.93 in Equation (3), respectively. It implies that control of corruption had to be higher than 4.92 (ICRG) and 0.93 (WGI) to bring overwhelm to the negative impacts of public debt totally. Meanwhile, the coefficients of the interaction 
The Relationship Between Public Debt, Budget Deficit, and Sustainable Economic Development ...

variable between budget deficit and corruption, Interact3, and Interact4, got 0.00131 and 0.00397 , respectively. Based on Equation (6), we found that the threshold value of control of corruption was 2.81 (ICRG) and 0.62 (WGI) for Equation (4). Enhancing the control of corruption will promote both sustainable economic development and reducing the negative impacts of public debt as well as the budget deficit.

Table 4 The relationship between public debt, budget deficit, and sustainable economic development

\begin{tabular}{|c|c|c|c|c|}
\hline \multirow[b]{2}{*}{$\begin{array}{l}\text { Independent } \\
\text { variable: } \\
\text { GDPPCGR }\end{array}$} & \multicolumn{2}{|c|}{ Model (3) } & \multicolumn{2}{|c|}{ Model (4) } \\
\hline & $\begin{array}{c}\text { Corruption } \\
\text { indicator 1: ICRG } \\
\text { (1) }\end{array}$ & $\begin{array}{c}\text { Corruption } \\
\text { indicator 2: WGI } \\
\text { (2) }\end{array}$ & $\begin{array}{l}\text { Corruption } \\
\text { indicator 1: } \\
\text { ICRG } \\
\text { (1) }\end{array}$ & $\begin{array}{c}\text { Corruption } \\
\text { indicator 2: } \\
\text { WGI } \\
\text { (2) }\end{array}$ \\
\hline $\log (G d p p c)$ & $\begin{array}{c}-0.09459 * * * \\
{[-31.61]}\end{array}$ & $\begin{array}{c}-0.94108 * * * \\
{[-46.40]}\end{array}$ & $\begin{array}{c}-0.99057 * * * \\
{[-47.62]}\end{array}$ & $\begin{array}{c}-0.09641 * * * \\
{[-46.52]}\end{array}$ \\
\hline Debt & $\begin{array}{c}-0.08283 * * * \\
{[-16.37]}\end{array}$ & $\begin{array}{c}-0.07980 * * * \\
{[-21.09]}\end{array}$ & $\begin{array}{c}-0.05668 * * * \\
{[-13.73]}\end{array}$ & $\begin{array}{c}-0.48075 * * * \\
{[-17.70]}\end{array}$ \\
\hline Deficit & $\begin{array}{c}-0.00113 * * * \\
{[-38.19]}\end{array}$ & $\begin{array}{c}-0.00106 * * * \\
{[-22.31]}\end{array}$ & $\begin{array}{c}-0.00368 * * * \\
{[-10.27]}\end{array}$ & $\begin{array}{c}-0.00247^{* * *} \\
{[-18.23]}\end{array}$ \\
\hline Debt*Corr1 & $\begin{array}{c}0.01681 * * * \\
{[6.87]}\end{array}$ & & & \\
\hline Debt*Corr2 & & $\begin{array}{c}0.08541 * * * \\
{[6.80]}\end{array}$ & & \\
\hline Deficit*Corr1 & & & $\begin{array}{c}0.00131 * * * \\
{[7.29]}\end{array}$ & \\
\hline Deficit*Corr2 & & & & $\begin{array}{c}0.00397^{* * *} \\
{[6.37]}\end{array}$ \\
\hline Gsize & $\begin{array}{c}0.00223 * * * \\
{[13.14]}\end{array}$ & $\begin{array}{c}0.00201 * * * \\
{[13.34]}\end{array}$ & $\begin{array}{c}0.00234 * * * \\
{[12.93]}\end{array}$ & $\begin{array}{c}0.00279 * * * \\
{[22.65]}\end{array}$ \\
\hline Infl & $\begin{array}{c}0.00059 * * * \\
{[15.34]}\end{array}$ & $\begin{array}{c}0.00064 * * * \\
{[26.03]}\end{array}$ & $\begin{array}{c}0.00059 * * * \\
{[27.28]}\end{array}$ & $\begin{array}{c}0.00057 * * * \\
{[16.81]}\end{array}$ \\
\hline Trade & $\begin{array}{c}0.00070 * * * \\
{[5.73]}\end{array}$ & $\begin{array}{c}0.00071 * * * \\
{[10.92]}\end{array}$ & $\begin{array}{c}0.00030 * * * \\
{[5.70]}\end{array}$ & $\begin{array}{c}0.00066 * * * \\
{[9.77]}\end{array}$ \\
\hline Human & $\begin{array}{c}0.11383^{* * *} \\
{[5.73]}\end{array}$ & $\begin{array}{c}0.11068^{* * *} \\
{[5.83]}\end{array}$ & $\begin{array}{c}0.16311 * * * \\
{[13.33]}\end{array}$ & $\begin{array}{c}0.13627^{* * *} \\
{[8.20]}\end{array}$ \\
\hline Const. & $\begin{array}{c}0.85558^{* * *} \\
{[28.75]}\end{array}$ & $\begin{array}{c}0.86175^{* * *} \\
{[27.45]}\end{array}$ & $\begin{array}{c}0.83467 * * * \\
{[33.09]}\end{array}$ & $\begin{array}{c}0.82346 * * * \\
{[31.63]}\end{array}$ \\
\hline $\operatorname{AR}(1)$ & 0.531 & 0.450 & 0.411 & .595 \\
\hline$A R(2)$ & 0.887 & 0.950 & 0.935 & 0.932 \\
\hline Hansen & 0.242 & 0.238 & 0.179 & 0.229 \\
\hline Num. group & 59 & 59 & 59 & 59 \\
\hline Num. IV & 58 & 58 & 58 & 58 \\
\hline Obs & 677 & 677 & 677 & 677 \\
\hline Threshold & 4.92 & 0.93 & 2.81 & 0.62 \\
\hline
\end{tabular}

Note: $\left({ }^{*}\right),(* *)$, and $(* * *)$ are $10 \%, 5 \%$, and $1 \%$, respectively, z-statistic in [ ]

Source: Author, 2020 
The Relationship Between Public Debt, Budget Deficit, and Sustainable Economic Development ...

The regression coefficients of Gsize in Table 3 and Table 4 range from 0.00138 to 0.00279 , and they are statistically significant at $1 \%$. This result showed that when the size of governments in the previous four years increased, it would enhance sustainable economic development in the long-term. The more government spending is, the more infrastructure will be created. Thus, they will reduce production costs, input costs of business activities, thereby increasing the income of the economy as well as promoting economic growth. Moreover, government spending on health and education will improve the human health, knowledge sharing, and skills of the workforce, thereby boosting the productivity of national labor. As a result, the output of the economy will be enhanced. Our result is similar to previous studies by Chowdhury (2001), Wahab and Holland (2012), and Alshahrani and Alsadiq (2014).

The coefficients of Inf in Table 3 and Table 4 fluctuate from 0.00058 to 0.00078 , and they are statistically significant at $1 \%$. This result revealed that inflation could boost sustainable economic development when its rate in the previous four years increased. It reflects the theory of the Philips curve because inflation will be able to stimulate economic growth by minimizing the nation's unemployment rate. Our findings are similar to the findings of Cho wdhury (2001); Rapach (2003); and Benhabib and Spiegel (2009).

In Table 3 and Table 4, Trade has regression coefficients, which range from 0.00030 to 0.00079 , and they are both statistically significant at the $1 \%$ level. It illustrates that the trade openness of the previous four years improved the countries' sustainable economic growth statistically. It can be explained that a country with a high degree of integration with the world can increase its exports and imports. On the one hand, it can boost domestic production productivity for export. On the other hand, it creates an opportunity to import technology and knowledge from the outside. As a result, it can improve the productivity of the economy and lead to a higher level of sustainable economic growth. Our findings are similar to the findings of Baum, Checherita-Westphal, \& Rother (2013), Kim et al. (2017), and Phung et al. (2019).

Lastly, Human receives coefficients which were from 0.04605 to 0.16311 , and they were statistically significant at the $1 \%$ level. They showed that high human capital had a positive impact on sustainable economic development. The improvement of human capital will be to attract foreign investors as well as promote innovation activities in the country (Grossman, 2000). In turn, innovation will promote sustainable economic growth (Phung et al., 2019). Our results are similar to the findings of previous authors, such as Woo and Kumar (2015); and Kim Kim et al. (2017).

\section{Conclusion}

This study investigates the effects of public debt and budget deficits on sustainable economic development of developing countries, meanwhile expanding to explore the role of control of corruption in these relations. By using the two-step GMM method for unbalanced panel data of 59 developing countries from 2004 to 2015, the study found that public debt and budget deficits had negative influences on sustainable economic 
The Relationship Between Public Debt, Budget Deficit, and Sustainable Economic Development ...

development while controlling corruption had a positive impact on sustainable economic development. Countries with high public debt will create situations in which it reduces investment, creates crowding-out effects of private investment and potential economic uncertainty. As a result, public debt impedes the sustainable economic growth of nations. Similarly, budget deficits cause an increase in the cost of financial debt, thus threatening the sustainability of fiscal policy as it leads to an increase in public debt and a failure to allocate national resources. Consequently, budget deficits also hinder the process of sustainable economic growth. However, using, in turn, an interactive variable between controlling corruption and public debt or budget deficits, the study found that countries with good levels of control of corruption limited the negative impacts of public debt and budget deficit on sustainable economic growth. In other words, for countries with high levels of control of corruption, an increase in public debt or budget deficits will lead to higher sustainable economic growth than countries with low levels of control of corruption. Low corruption will be able to increase investment, reduce inflation, increase national productivity, pushing economic growth. Good control of corruption brings the chance for improving competition and innovation, leading to a comfortable business environment. Moreover, good control of corruption also reduces the stress of budget deficit as well as a public debt due to a good allocation of resources and transparency of government expenditure. Consequently, it leads to sustainable growth and plays an active role in reducing the negative effects of corruption, thereby promoting sustainable economic development.

Based on the results, this study provides some policy implications. First, developing countries should not consider to raise public debt or maintain budget deficits as keys for economic development if the government's goal is to aim for sustainable economic growth. Instead of that, developing countries need to increase the quality of control of corruption to create a competitive and transparent of the business environment, promote private investment, and reduce instability of the economy in cases of wanting to use budget deficits as an expansionary fiscal policy to boost economic spending, investment, and consumption. Control of corruption also encourages more creative and productive social activities. In addition, for countries with good levels of control of corruption, the use of public debt can be considered as a solution to complement the nation's resources. Finally, the government can implement policies that aim to increase consumption, open greater integration, and invest heavily in human capital so they can improve sustainable economic development in the long-term.

\section{References}

Abbas, S. M. A., \& Christensen, J. E. (2009). The Role of Domestic Debt Markets in Economic Growth: An Empirical Investigation for Low-Income Countries and Emerging Markets. IMF Staff Papers, 57(1), 209-255.

https://doi.org/10.1057/imfsp.2009.24

Abed, G. T., \& Davoodi, H. R. (2000). Corruption, Structural Reforms, and Economic Performance in the Transition Economies. IMF Working Papers, 00(132), 1. https://doi.org/10.5089/9781451855371.001 
The Relationship Between Public Debt, Budget Deficit, and Sustainable Economic Development ...

Afonso, A., \& Alves, J. R. (2014). The Role of Government Debt in Economic Growth. SSRN Electronic Journal. https://doi.org/10.2139/ssrn.2468805

Agnello, L., \& Sousa, R. M. (2013). Political, Institutional, and Economic Factors Underlying Deficit Volatility. Review of International Economics, 21(4), 719-732. https://doi.org/10.1111/roie.12066

Alesina, A., Mirrlees, J., \& Neumann, M. J. M. (1989). Politics and Business Cycles in Industrial Democracies. Economic Policy, 4(8), 55. https://doi.org/10.2307/1344464

Ali, R., \& Mustafa, U. (2012). External Debt Accumulation and Its Impact on Economic Growth in Pakistan. The Pakistan Development Review, 51(4II), 79-96. https://doi.org/10.30541/v51i4iipp.79-96

Al-Marhubi, F. A. (2000). Corruption and Inflation. Economics Letters, 66(2), 199-202. https://doi.org/10.1016/s0165-1765(99)00230-x

Alshahrani, S., \& Alsadiq, A. (2014). Economic Growth and Government Spending in Saudi Arabia: An Empirical Investigation. IMF Working Papers, 14(3), 1. https://doi.org/10.5089/9781484348796.001

Anita, Č Č. Ana, A. B., \& Martina, B. S. (2014). Public Debt and Growth: Evidence from Central, Eastern and Southeastern European Countries. Zb. rad. Ekon. fak. Rij., 32(1), 35-51. Retrieved from https://ideas.repec.org/a/rfe/zbefri/v32y2014i1p35$\underline{51 . h t m l}$

Bal, D. P., \& Rath, B. N. (2014). Public Debt and Economic Growth in India: A Reassessment. Economic Analysis and Policy, 44(3), 292-300. https://doi.org/10.1016/i.eap.2014.05.007

Baldacci, E., Cui, Q., Clements, B. J., \& Gupta, S. (2004). Social Spending, Human Capital, and Growth in Developing Countries: Implications for Achieving the Mdgs. IMF Working Papers, 04(217), 1. https://doi.org/10.5089/9781451875140.001

Barişik, S., \& Baris, A. (2017). Impact of Governance on Budget Deficit in Developing Countries. Theoretical and Applied Economics, XXIV(2), 111-130. Retrieved from http://store.ectap.ro/articole/1272.pdf

Barro, R. (1995). Inflation and Economic Growth. NBER Working Paper, National Bureau of Economic Research Cambridge. Retrieved from http://dx.doi.org/10.3386/w5326

Barro, R. J., \& Lee, J. W. (2013). A New Data Set of Educational Attainment in the World, 1950-2010. Journal of Development Economics, 104, 184-198. https://doi.org/10.1016/j.jdeveco.2012.10.001

Baum, A., Checherita-Westphal, C., \& Rother, P. (2013). Debt and Growth: New Evidence for the Euro Area. Journal of International Money and Finance, 32, 809-821. https://doi.org/10.1016/i.jimonfin.2012.07.004

Benhabib, J., \& Spiegel, M. M. (2009). Moderate Inflation and the Deflation-Depression Link. Journal of Money, Credit and Banking, 41(4), 787-798. https://doi.org/10.1111/j.1538-4616.2009.00232.x

Blackburn, K., Bose, N., \& Emranul Haque, M. (2006). The Incidence and Persistence of Corruption in Economic Development. Journal of Economic Dynamics and Control, 30(12), 2447-2467. https://doi.org/10.1016/j.jedc.2005.07.007

Brunetti, A., \& Weder, B. (2003). A Free Press Is Bad News for Corruption. Journal of Public Economics, 87(7-8), 1801-1824. https://doi.org/10.1016/s0047-2727(01)00186-4

Bruno, M., \& Easterly, W. (1998). Inflation Crises and Long-Run Growth. Journal of Monetary Economics, 41(1), 3-26. https://doi.org/10.1016/s0304-3932(97)00063-9

Buiter, W. H. (1977). Crowding out' and the Effectiveness of Fiscal Policy. Journal of Public Economics, 7(3), 309-328. https://doi.org/10.1016/0047-2727(77)90052-4

Calderón, C., \& Fuentes, J. R. (2013). Government Debt and Economic Growth. Inter-American Development Bank. Retrieved from: 
The Relationship Between Public Debt, Budget Deficit, and Sustainable Economic Development ...

https://publications.iadb.org/publications/english/document/Government-Debtand-Economic-Growth.pdf

Campos, J. E., Lien, D., \& Pradhan, S. (1999). The Impact of Corruption on Investment: Predictability Matters. World Development, 27(6), 1059-1067. https://doi.org/10.1016/s0305-750x(99)00040-6

Cerra, V., Rishi, M., \& Saxena, S. C. (2008). Robbing the Riches: Capital Flight, Institutions and Debt. The Journal of Development Studies, 44(8), 1190-1213. https://doi.org/10.1080/00220380802242453

Chowdhury, A. (2001). External Debt and Growth in Developing Countries. In (Vol. 2001). Helsinki, Finland: UNU-WIDER.

Chowdhury, S. D., \& Michael Geringer, J. (2001). Institutional Ownership, Strategic Choices and Corporate Efficiency: Evidence from Japan. Journal of Management Studies, 38(2), 271-292. https://doi.org/10.1111/1467-6486.00236

Clements, B., Gupta, S., \& Inchauste, G. (2004). Fiscal Policy for Development: An Overview. In Helping Countries Develop: The Role of Fiscal Policy. Retrieved from https://www.imf.org/external/pubs/nft/2004/hcd/ch01.pdf

Cohen, K. J., Hawawini, G. A., Maier, S. F., Schwartz, R. A., \& Whitcomb, D. K. (1983). Friction in the Trading Process and the Estimation of Systematic Risk. Journal of Financial Economics, 12, 263-278. https://doi.org/10.1016/0304-405x(83)90038-7

Cooray, A., Dzhumashev, R., \& Schneider, F. (2017). How Does Corruption Affect Public Debt? An Empirical Analysis. World Development, 90, 115-127. https://doi.org/10.1016/i.worlddev.2016.08.020

DiPeitro, W. R., \& Anoruo, E. (2012). Government Size, Public Debt and Real Economic Growth: A Panel Analysis. Journal of Economic Studies, 39(4), 410-419. https://doi.org/10.1108/01443581211255620

Dort, T., Méon, P.-G., \& Sekkat, K. (2014). Does Investment Spur Growth Everywhere? Not Where Institutions Are Weak. Kyklos, 67(4), 482-505. https://doi.org/10.1111/kykl.12064

Eberhardt, M., \& Presbitero, A. F. (2015). Public Debt and Growth: Heterogeneity and Non-Linearity. Journal of International Economics, 97(1), 45-58. https://doi.org/10.1016/i.jinteco.2015.04.005

Égert, B. (2015). Public Debt, Economic Growth and Nonlinear Effects: Myth or Reality? Journal of Macroeconomics, 43, 226-238. https://doi.org/10.1016/j.jmacro.2014.11.006

Égert, B. (2016). Regulation, Institutions, and Productivity: New Macroeconomic Evidence from Oecd Countries. American Economic Review, 106(5), 109-113. https://doi.org/10.1257/aer.p20161026

Elmendorf, D. W., \& Mankiw, N. G. (1999). Government Debt. In Handbook of Macroeconomics (pp. 1615-1669): Elsevier.

Fatima, G., Ahmed, M., \& Rehman, W. U. (2012). Consequential Effects of Budget Deficit on Economic Growth of Pakistan. International Journal of Business and Social Science, 3(7), 203-208.

Figuières, C., Masclet, D., \& Willinger, M. (2012). Vanishing Leadership and Declining Reciprocity in a Sequential Contribution Experiment. Economic Inquiry, 50(3), 567584. https://doi.org/10.1111/i.1465-7295.2011.00415.x

Gaber, S. (2010). Economic Implications from Deficit Finance. Working Paper. Bamberg University. Retrieved from https://www.econstor.eu/bitstream/10419/38828/1/617386072.pdf

Gochoco, M. S. (1990). Financing Decisions and the 'Crowding out' Effect. Economics Letters, 32(4), 331-333. https://doi.org/10.1016/0165-1765(90)90024-u 
The Relationship Between Public Debt, Budget Deficit, and Sustainable Economic Development ...

Grossman, M. (2000). The Human Capital Model. In A. J. Culyer \& J. P. Newhouse (Eds.), Handbook of Health Economics (Vol. 1, pp. 347-408): Elsevier.

Ha, N. T. T., \& Quyen, P. G. (2018). Monetary policy, bank competitiveness and bank risktaking: Empirical evidence from Vietnam. Asian Academy of management Journal of Accounting and Finance, 14(2), 137-156. https://doi.org/10.21315/aamjaf2018.14.2.6

Ha, N. T. T., Van, V. T. T., Thu, P. A., \& Anh, L. T. H. (2019). Institutional Environment, Government Ownership and Firm Profitability: Empirical Evidence from Vietnam. Academy of Accounting and Financial Studies Journal, 23(3), 1-11. Retrieved from https://www.abacademies.org/articles/institutional-environment-governmentownership-and-firm-profitability-empirical-evidence-from-vietnam-8283.html

Harcourt, G. C., \& Coddington, A. (1984). Keynesian Economics: The Search for First Principles. Economica, 51(202), 207. https://doi.org/10.2307/2554213

Heutel, G. (2012). Crowding out and Crowding in of Private Donations and Government Grants. Public Finance Review, 42(2), 143-175.

https://doi.org/10.1177/1091142112447525

Hussain, M. E., Haque, M., \& Igwike, R. S. (2015). Relationship between Economic Growth and Debt: An Empirical Analysis for Sub-Saharan Africa. Journal of Economics and Political Economy, 2(2), 262-276. Retrieved from http://kspjournals.org/index.php/JEPE/article/view/222

Hwang, J.-T., Chung, C.-P., \& Wang, C.-H. (2010). Debt Overhang, Financial Sector Development and Economic Growth. Hitotsubashi Journal of Economics, 51(1), 13-30. Retrieved from https://www.researchgate.net/publication/44930086 Debt overhang financial sec tor development and economic growth

Karras, G. (1994). Macroeconomic Effects of Budget Deficits: Further International Evidence. Journal of International Money and Finance, 13(2), 190-210. https://doi.org/10.1016/0261-5606(94)90015-9

Kaufman, D. (2010). Can Corruption Adversely Affect Public Finance in Industrialized Countries? : Brookings Institution Opinions.

Khan, M. A., Khan, M. Z., \& Zaman, K. (2012). Measuring the Impact of Fiscal Variables on Economic Growth in Pakistan: New Light on an Old Problem. Journal of Economic and Social Research, 14(2), 53-82.

Kim, E., Ha, Y., \& Kim, S. (2017). Public Debt, Corruption and Sustainable Economic Growth. Sustainability, 9(3), 433. https://doi.org/10.3390/su9030433

Krugman, P. (1988). Financing Vs. Forgiving a Debt Overhang. Journal of Development Economics, 29(3), 253-268. https://doi.org/10.1016/0304-3878(88)90044-2

Lambsdorff, J. G. (2003). How Corruption Affects Productivity. Kyklos, 56(4), 457-474. https://doi.org/10.1046/j.0023-5962.2003.00233.x

Liaqat, Z. (2019). Does Government Debt Crowd out Capital Formation? A Dynamic Approach Using Panel Var. Economics Letters, 178, 86-90.

https://doi.org/10.1016/j.econlet.2019.03.002

Madni, G. R., \& Chaudhary, M. A. (2017). Economic Growth in Context of Institutions and Fiscal Policy. Pakistan Economic and Social Review, 55(1), 79-98. Retrieved from http://pu.edu.pk/images/journal/pesr/PDF-FILES/5-v55 1 17.pdf

Matiti, C. (2013). The Relationship between Public Debt and Economic Growth in Kenya. International Journal of Social Sciences and Project Planning Management, 1(1), 1-21. Retrieved from https: / www.google.com/url? sa $=$ t\&rct $=j \& q=\& e s r c=s \&$ source $=$ web\&cd $=1 \& \mathrm{cad}=\mathrm{r}$ ja\&uact $=8 \& v e d=2$ ahUKEwjU6dOB6Z7pAhXWbCsKHTxAPMQFjAAegQIAxAB\&url=http $\% 3 \mathrm{~A} \% 2 \mathrm{~F} \% 2$ Ferepository.uonbi.ac.ke $\% 2 \mathrm{Fbitstrea}$ 
The Relationship Between Public Debt, Budget Deficit, and Sustainable Economic Development ...

m\%2Fhandle $\% 2$ F11295\%2F92361\%2FMatiti The\%2520relationship $\% 2520$ betwee n $\% 2520$ public $\% 2520 \mathrm{debt}^{2} \% 2520$ and $\% 2520$ economic $\% 2520$ growth.pdf $\% 3$ Fsequenc e \%3D1\%26isAllowed \%3Dy\&usg=AOvVaw1qe8Qqw3-bDaNnftgXCbZY

Mauro, P. (1995). Corruption and Growth. The Quarterly Journal of Economics, 110(3), 681-712. https://doi.org/10.2307/2946696

Metwally, M. M., \& Tamaschke, R. (1994). The Interaction among Foreign Debt, Capital Flows, and Growth: Case Studies. Journal of Policy Modeling, 16(6), 597-608. https://doi.org/10.1016/0161-8938(94)90010-8

Morrissey, O., \& Udomkerdmongkol, M. (2012). Governance, Private Investment and Foreign Direct Investment in Developing Countries. World Development, 40(3), 437 445. https://doi.org/10.1016/i.worlddev.2011.07.004

North, D. C. (1990). Institutions, Institutional Change and Economic Performance. New York: Cambridge University Press.

Okelo, S. O., Momanyi, G., Othuon, L., \& Fredrick, O. A. (2013). The Relationship between Fiscal Deficits and Economic Growth in Kenya: An Empirical Investigation. Greener Journal of Social Sciences, 3(6), 306-323. https://doi.org/10.15580/gjss.2013.6.051113603

Panizza, U., \& Presbitero, A. F. (2013). Public Debt and Economic Growth in Advanced Economies: A Survey. Swiss Journal of Economics and Statistics, 149(2), 175-204. https://doi.org/10.1007/bf03399388

Panizza, U., \& Presbitero, A. F. (2014). Public Debt and Economic Growth: Is There a Causal Effect? Journal of Macroeconomics, 41, 21-41. https://doi.org/10.1016/j.jmacro.2014.03.009

Pattillo, C., Poirson, H., \& Ricci, L. A. (2011). External Debt and Growth. Review of Economics and Institutions, 2(3) 1-30. https://doi.org/10.5202/rei.v2i3.45

Pezzey, J. (1992). Sustainable Development Concept: The World Bank.

Phung, T. D., Van, V. T. T., Thuong, T. T. H., \& Ha, N. T. T. (2019). Innovation and Economic Growth: The Contribution of Institutional Quality and Foreign Direct Investment. Asian Economic and Financial Review, 9(11), 1266-1278. https://doi.org/10.18488/journal.aefr.2019.911.1266.1278

Rapach, D. E. (2003). International Evidence on the Long-Run Impact of Inflation. Journal of Money, Credit and Banking, 35(1), 23-48. Retrieved from https:/ / www.google.com/url?sa=t\&rct=j\&q=\&esrc=s\&source=web\&cd =1\&cad =r ja\&uact $=8 \&$ ved $=2$ ahUKEwj81aqI6p7pAhXMF3IKHSEGDoEQFjAAegQIAhAB \&url $=$ https $\% 3 \mathrm{~A} \% 2 \mathrm{~F} \% 2 \mathrm{Feconpapers.repec.org} \% 2 \mathrm{FRePEc} \% 3 \mathrm{Amcb} \% 3 \mathrm{Ajmoncb} \% 3$ Av $\% 3 \mathrm{~A} 35 \% 3 \mathrm{Ay} \% 3 \mathrm{~A} 2003 \% 3 \mathrm{Ai} \% 3 \mathrm{~A} 1 \% 3 \mathrm{Ap} \% 3 \mathrm{~A} 23$ 48\&usg=AOvVaw1qNKNQhyMjxeEM-jUGCINA

Reinhart, C. M., Reinhart, V. R., \& Rogoff, K. S. (2012). Public Debt Overhangs: AdvancedEconomy Episodes since 1800. Journal of Economic Perspectives, 26(3), 69-86. https://doi.org/10.1257/jep.26.3.69

Rodrik, D. (2005). Growth Strategies. In Handbook of Economic Growth (pp. 967-1014): Elsevier.

Roodman, D. (2009). How to Do Xtabond2: An Introduction to Difference and System Gmm in Stata. The Stata Journal, 9, 86-136. Retrieved from https: / / www.google.com/url? sa $=$ t\&rct=j\&q $=$ \&esrc $=$ s\&source $=$ web\&cd $=1 \& \mathrm{cad}={ }_{1}$ ja\&uact $=8 \& v e d=2$ ahUKEwiGlZme6p7pAhWWV30KHQ2YD8EQFjAAegQIAxA B\&url=https $\% 3 \mathrm{~A} \% 2 \mathrm{~F} \% 2 \mathrm{Fjournals.sagepub.com} \% 2 \mathrm{Fdoi} \% 2 \mathrm{~F} 10.1177 \% 2 \mathrm{~F} 1536867$ $\underline{\text { X0900900106\&usg=AOvVaw3J2knpDuviSTR9wGqK2fl9 }}$ 
The Relationship Between Public Debt, Budget Deficit, and Sustainable Economic Development ...

Savvides, A. (1992). Investment Slowdown in Developing Countries During the 1980s: Debt Overhang or Foreign Capital Inflows? Kyklos, 45(3), 363-378. https://doi.org/10.1111/j.1467-6435.1992.tb02121.x

Schneider, F., Buehn, A., \& Montenegro, C. E. (2010). New Estimates for the Shadow Economies All over the World. International Economic Journal, 24(4), 443-461. https://doi.org/10.1080/10168737.2010.525974

Sen, S., Kasibhatla, K. M., \& Stewart, D. B. (2007). Debt Overhang and Economic Growththe Asian and the Latin American Experiences. Economic Systems, 31(1), 3-11. https://doi.org/10.1016/i.ecosys.2006.12.002

Šimić, V., \& Vinko, M. (2012). Debts (Public and External) and Growth - Link or No Link? Croatian Operational Research Review, 3(1), 91-102. Retrieved from https://hrcak.srce.hr/96805

Tanzi, V., \& Davoodi, H. (2001). Corruption, Growth, and Public Finances. Routledge Contemporary Economic Policy Issues: Routledge. https://doi.org/10.4324/9780203468388.pt3

Tanzi, V., \& Zee, H. H. (1997). Fiscal Policy and Long-Run Growth. Staff Papers, 44(2), 179209. https://doi.org/10.2307/3867542

Tarek, B. A., \& Ahmed, Z. (2017). Institutional Quality and Public Debt Accumulation: An Empirical Analysis. International Economic Journal, 31(3), 415-435. https://doi.org/10.1080/10168737.2017.1354906

Tung, L. T. (2018). The Effect of Fiscal Deficit on Economic Growth in an Emerging Economy: Evidence from Vietnam. Journal of International Studies, 11(3), 191-203. https://doi.org/10.14254/2071-8330.2018/11-3/16

Van, V. B., \& Sudhipongpracha, T. (2015). Exploring Government Budget Deficit and Economic Growth: Evidence from Vietnam's Economic Miracle. Asian Affairs: An American Review, 42(3), 127-148. https://doi.org/10.1080/00927678.2015.1048629

Wahab, N. S. A., \& Holland, K. (2012). Tax Planning, Corporate Governance and Equity Value. The British Accounting Review, 44(2), 111-124. https://doi.org/10.1016/j.bar.2012.03.005

Wei, S.-J. (2000). How Taxing Is Corruption on International Investors? Review of Economics and Statistics, 82(1), 1-11. https://doi.org/10.1162/003465300558533

Woo, J. (2003). Economic, Political, and Institutional Determinants of Public Deficits. Journal of Public Economics, 87(3-4), 387-426. https://doi.org/10.1016/s00472727(01)00143-8

Woo, J., \& Kumar, M. S. (2015). Public Debt and Growth. Economica, 82(328), 705-739. https://doi.org/10.1111/ecca.12138

Wright, A., \& Grenade, K. (2014). Determining Optimal Public Debt and Debt-Growth Dynamics in the Caribbean. Research in Applied Economics, 6(2), 87-115. https://doi.org/10.5296/rae.v6i2.5577

Wrigley, E. A. (1988). The Limits to Growth: Malthus and the Classical Economists. Population and Development Review, 14(1), 30-48 https://doi.org/10.2307/2808089

Zouhaier, H., \& Fatma, M. (2014). Debt and Economic Growth. International Journal of Economics and Financial Issues, 4(2), 440-448. Retrieved from https://www.google.com/url? sa =t\&rct=j\&q=\&esrc=s\&source=web\&cd=1\&cad = rja \&uact=8\&ved =2ahUKEwjMsrLU657pAhUIcCsKHeWoCHIQFjAAegQIARAB\&url $=$ https $\% 3 \mathrm{~A} \% 2 \mathrm{~F} \% 2 \mathrm{Fwww}$.econjournals.com $\% 2$ Findex.php $\% 2 \mathrm{Fijefi} \% 2 \mathrm{Farticle} \% 2 \mathrm{Fvi}$ ew $\% 2 F 759 \& u s g=A O v V a w 0 W w 5 s U R m P F A 5 b b I J 4-r M x V$ 